\title{
EFEKTIVITAS EKSTRAK ETANOL DAUN BELUNTAS PLUCHEA INDICA (L.) LESS TERHADAP BAKTERI SALIVA SECARA IN VITRO
}

\author{
Annisa Fairus Syafira*, Masyhudi**, Sinar Yani***
}

Keywords:

Bacteria, Ethanol, Extraction, Pluchea indica (L.) Less, Salivary

\section{ABSTRACT}

Background: Pluchea indica (L.) Less leaf contains antibacteria substances that can inhibit the growth of bacteria that cause dental and oral diseases. Previous research shows that Pluchea indica (L.) Less leaf extract can inhibit the growth of Escherichia coli, Staphylococcus aureus and Pseudomonas aeruginosa bacteria. This research aimed to find out effectiveness of Pluchea indica (L.) Less leaves to decrease in the number of salivary bacteria colony.

Method: This research used a sample of saliva obtained from a person who has dental caries. The saliva had been treated with Pluchea indica (L.) Less leaves ethanol extract with concentration 2,5\%,3,5\%,4,5\%,5,5\%, and 6,5\%. Bacterial colonies were calculated using a colony counter and no identification was performed.

Result: The mean of bacteria colony number in Plate Count Agar media without Pluchea indica (L.) Less leaves ethanol extract is 142,67. After being given Pluchea indica (L.) Less leaves ethanol extract with concentration of 2,5\%, 3,5\%, and 4,5\%, the mean of bacteria colony number sequentially are 15,67, 10,67, 4, and at a concentration of $5.5 \%$ and $6.5 \%$ no more bacterial colonies were found.

Conclusion: Pluchea indica (L.) Less leaves ethanol extract effective to inhibit and eliminate oral bacteria.

\section{PENDAHULUAN}

Kesehatan rongga mulut merupakan hal yang penting karena berhubungan dengan kesehatan tubuh secara keseluruhan. Hasil Riset Kesehatan Dasar (Riskesdas) menunjukkan dalam 12 bulan terakhir (potential demand) prevalensi penduduk yang mempunyai masalah gigi dan mulut sebesar 25,9\%. Data tersebut menunjukkan terdapat $31,1 \%$ yang menerima perawatan dan pengobatan dari tenaga medis gigi (perawat gigi, dokter gigi atau dokter gigi spesialis), sementara $68,9 \%$ lainnya tidak dilakukan perawatan 1.Prevalensi masalah kesehatan gigi dan mulut di Samarinda sampai tahun 2014 sebesar 52,6\% (419.535).
Dalam rongga mulut terdapat banyak mikroorganisme, hal ini dikarenakan rongga mulut menjadi pintu gerbang dari saluran pencernaan. Berbagai macam mikroflora normal menghuni bagian-bagian atau permukaan yang berbeda dari rongga mulut seperti pada plak gigi, cairan sulkus gingiva, mucus membrane, dorsum lidah, saliva dan mukosa mulut 2,3,4.

Keberadaan flora normal pada bagian tubuh tertentu memiliki peran yang penting dalam pertahanan tubuh karena menghasilkan suatu zat yang dapat menghambat pertumbuhan mikroorganisme lain.

\footnotetext{
* Program Studi Kedokteran Gigi, Fakultas Kedokteran Universitas Mulawarman

** Departemen Mikrobiologi, Program Studi Kedokteran Gigi, Fakultas Kedokteran Universitas Mulawarman ${ }^{* * * D e p a r t e m e n ~ B i o l o g i ~ O r a l, ~ P r o g r a m ~ S t u d i ~ K e d o k t e r a n ~ G i g i, ~ F a k u l t a s ~ K e d o k t e r a n ~ U n i v e r s i t a s ~ M u l a w a r m a n ~}$ Korespondensi: fairussyafirannisa96@gmail.com
} 
Bakteri Streptoccus sp. merupakan bakteri dominan dalam rongga mulut, selain itu terdapat juga Staphylococcus sp. dan Lactobacillus sp. Bakteri-bakteri tersebut dapat ditemukan dalam rongga mulut termasuk di saliva, dalam $1 \mathrm{ml}$ saliva terdapat 1 sampai 100 juta bakteri $5,6,7$.

Flora normal tersebut tidak selalu menguntungkan, dalam kondisi tertentu flora normal dapat menimbulkan penyakit, misalnya bila terjadi perubahan substrat atau berpindah dari habitat yang semestinya, sehingga menyebabkan penyakit seperti karies dan penyakit periodontal ${ }^{8,9}$.

Saat ini sudah banyak upaya pencegahan untuk penyakit gigi karies dengan penggunaan obat kumur yang menggunakan bahan kimia sehingga dapat menimbulkan efek negatif dalam rongga mulut 10,11 . Seiring dengan berjalannya waktu, banyak penelitian telah dilakukan dan ditemukan tanaman herbal yang memiliki potensi besar sebagai obat pencegah penyakit gigi dan mulut, salah satunya adalah daun beluntas Pluchea indica (L.) Less. Beluntas Pluchea indica (L.) Less adalah tumbuhan yang mudah dijumpai di Indonesia, biasa tumbuh liar di daerah kering pada tanah yang keras dan berbatu, atau ditanam sebagai tanaman pagar. Tumbuhan ini memiliki aroma yang khas dan rasanya getir. Bagian yang digunakan dari tumbuhan ini adalah daun dan akarnya yang berkhasiat untuk menghilangkan bau badan dan bau mulut, meningkatkan nafsu makan, mengatasi gangguan pencernaan pada anak-anak, menghilangkan nyeri pada rematik dan sebagainya ${ }^{12}$.

Penelitian yang dilakukan oleh Setyowati (2010), membuktikan bahwa daun beluntas Pluchea indica (L.) Less atau yang biasa disebut daun luntas oleh Suku Dayak Tunjung di Kalimantan Timur, daunnya biasa digunakan sebagai obat keputihan. Kandungan yang dimiliki tanaman beluntas Pluchea indica (L.) Less berada pada daun yang mengandung saponin, flavonoid, polifenol, dan alkaloid. Selain itu juga mengandung minyak atsiri, kalsium, asam chlorogenik, natrium, magnesium, dan fosfor ${ }^{13,14}$. Hasil penelitian yang dilakukan oleh Febriana et al., (2015), menunjukkan bahwa ekstrak daun beluntas Pluchea indica (L.) Less menyebabkan terhambatnya pertumbuhan bakteri Escherichia coli dan konsentrasi hambat minimal yang paling efektif dalam menghambat total pertumbuhan bakteri E. coli adalah $50 \%{ }^{15}$.

Penelitian ini menguji efektivitas ekstrak etanol daun beluntas (Pluchea indica (L.) Less) dalam menghambat koloni bakteri dalam saliva.

\section{METODE PENELITIAN}

Desain penelitian ini merupakan eksperimental murni untuk membandingkan antara media tanpa diberi ekstrak dengan yang diberi ekstrak. Protokol penelitian ini sudah disetujui oleh Komisi Etik Penelitian Fakultas Kedokteran Universitas Mulawaraman, dengan nomor kode etik NO.15/KEPK-FK/11/2018. Penelitian ini menggunakan sampel saliva yang diperoleh dari seseorang yang memiliki karies gigi. Penelitian ini menggunakan kontrol positif Clorhexidine gluconate $0,2 \%$ dan kontrol negatif aquades. Konsentrasi ekstrak yang digunakan adalah 2,5\%, 3,5\%, 4,5\%, 5,5\% dan $6,5 \%$. Pengulangan dilakukan sebanyak 3 kali.

Penelitian ini menggunakan etanol 96\%, sampel saliva, aquades steril, nutrient agar, clorhexidine gluconate $0,2 \%$, timbangan, botol steril, rotary evaporator, oven, toples kaca 
tertutup, lemari pengering, kertas saring, tabung reaksi, spidol, kertas label, autoclave, tabung Erlenmeyer, handschoon, masker, cawan petri, pot sampel, kertas saring Whatman® no.42, inkubator, micropipet, dan colony counter untuk menghitung jumlah koloni bakteri.

Penelitian ini menggunakan daun beluntas (Pluchea indica (L.) Less) yang sudah diidentifikasi di Laboratorium Dendrologi dan Ekologi hutan Fakultas Kehutanan Universitas Mulawarman. Daun beluntas (Pluchea inica (L.) Less) dicuci bersih dan dikeringkan dalam lemari pengering selama 7 hari. Daun yang sudah kering dihaluskan dengan cara diremas dan diblender. Daun yang sudah halus kemudian dimaserasi ke dalam pelarut etanol selama 3 hari dan dikocok setiap harinya. Ekstrak yang dihasilkan kemudian disaring menggunakan kertas saring Whatman ${ }^{\circledR}$ no.42 kemudian dipekatkan dengan menggunakan rotary evaporator. Selanjutnya didapatkan ekstrak pekat dikeringkan lebih lanjut dalam oven suhu $60^{\circ} \mathrm{C}$.

Prosedur penelitian terdiri dari tiga tahap. Tahap pertama ialah mengumpulkan dan mengencerkan sampel saliva. Saliva yang sudah dikumpulkan diencerkan sebanyak 5 kali. Siapkan 5 tabung dan masing-masing tabung berisi aquades steril sebanyak $9 \mathrm{ml}$. Masukkan $1 \mathrm{ml}$ sampel saliva ke dalam tabung pertama kemudian dihomogenisasikan. Ambil $1 \mathrm{ml}$ sampel dari tabung pertama dan masukkan ke dalam tabung ke kedua kemudian dihomogenisasikan. Lakukan hal serupa dari tiap tabung hingga ke tabung terakhir.

Tahap selanjutnya adalah pembuatan media untuk plate count agar tanpa ekstrak dan diberi ekstrak. Untuk membuat media plate count agar tanpa ekstrak siapkan bubuk nutrient agar sebanyak 4,3 g dan aquades steril sebanyak 250 ml. Masukkan aquades steril ke tabung erlenmeyer setelah itu masukkan bubuk nutrient agar. Kemudian lakukan sterilisasi dengan autoclave dengan suhu $121^{\circ} \mathrm{C}$ dengan tekanan 2 atm selama 15 menit. Kemudian tuang nutrient agar ke dalam 3 cawan petri masing-masingnya $10 \mathrm{ml}$, dan diamkan hingga padat. Untuk membuat media plate count agar dengan tambahan ekstrak, pertama membuat larutan stok ekstrak dengan konsentrasi $15 \%$ yaitu dengan mencampurkan 7,5 gram ekstrak kental dengan $50 \mathrm{ml}$ aquades steril. Kemudian untuk media PCA dengan tambahan ekstrak dengan konsentrasi 2,5\%, ambil 1,6 $\mathrm{ml}$ larutan stok 15\% kemudian ditambah dengan media PCA sebanyak $8,4 \mathrm{ml}$. Untuk media PCA dengan tambahan ekstrak dengan konsentrasi 3,5\%, ambil 2,3 $\mathrm{ml}$ larutan stok $15 \%$ kemudian ditambah dengan media PCA sebanyak 7,7 ml. Untuk media PCA dengan tambahan ekstrak dengan konsentrasi $4,5 \%$, ambil $3 \mathrm{ml}$ larutan stok 15\% kemudian ditambah dengan media PCA sebanyak $7 \mathrm{ml}$. Untuk media PCA dengan tambahan ekstrak dengan konsentrasi 5,5\%, ambil 3,6 ml larutan stok 15\% kemudian ditambah dengan media PCA sebanyak 6,4 $\mathrm{ml}$. Untuk media PCA dengan tambahan ekstrak dengan konsentrasi $6,5 \%$, ambil 4,3 ml larutan stok 15\% kemudian ditambah dengan media PCA sebanyak 5,7 ml. Masingmasing diamkan hingga media dengan ekstrak memadat.

Tahap terakhir ialah perhitungan jumlah koloni, ambil sampel saliva pada tabung pengenceran kelima mengunakan micropipet sebanyak $100 \mu \mathrm{l}$ kemudian tuang diatas media PCA tanpa dan dengan ekstrak kemudian ratakan menggunakan swab steril. Setelah itu lakukan 
inkubasi selama 24 jam dan keesokan harinya hitung jumlah koloni yang ada menggunakan colony counter.

\section{HASIL PENELITIAN}

Telah dilakukan penelitian mengenai uji efektivitas ekstrak etanol daun beluntas (Pluchea indica (L.) Less) terhadap bakteri saliva. Hasil
Analisa data dilakukan menggunakan SPSS for windows version 20. Uji statistik dengan menggunakan uji shapiro-wilk , kemudian dilanjutkan dengan independent $t$-test rata-rata jumlah koloni bakteri dalam saliva pada media tanpa dan dengan ekstrak dapat dilihat pada tabel 1

.Tabel 1: Hasil rata-rata jumlah koloni bakteri

\begin{tabular}{lcc}
\hline Jenis Perlakuan & $\begin{array}{c}\text { Mean Koloni Sebelum } \\
\text { Perlakuan } \pm \text { SD }\left(\times 10^{5}\right. \\
\text { CFU/ml })\end{array}$ & $\begin{array}{c}\text { Mean Koloni Sesudah } \\
\text { Perlakuan } \pm \text { SD }\left(\times \mathbf{1 0}^{5}\right. \\
\text { CFU } / \mathbf{m l})\end{array}$ \\
\hline Esktrak 2,5\% & $142,67 \pm 12,858$ & $15,67 \pm 10,066$ \\
\hline Esktrak 3,5\% & $142,67 \pm 12,858$ & $10,67 \pm 3,215$ \\
\hline Esktrak 4,5\% & $142,67 \pm 12,858$ & $4 \pm 0,000$ \\
\hline Esktrak 5,5\% & $142,67 \pm 12,858$ & $0,00 \pm 0,000$ \\
\hline Esktrak 6,5\% & $142,67 \pm 12,858$ & $0,00 \pm 0,000$ \\
\hline Kontrol Positif & $142,67 \pm 12,858$ & $0,00 \pm 0,000$ \\
\hline Kontrol Negatif & $142,67 \pm 12,858$ & $142,67 \pm 12,858$
\end{tabular}

Berdasarkan tabel 1 memperlihatkan bahwa terdapat penurunan jumlah koloni bakteri pada media tanpa ekstrak dan dengan diberi ekstrak setelah diinkubasi selama 24 jam pada suhu $37^{\circ} \mathrm{C}$. Penelitian ini mendapatkan hasil ratarata jumlah koloni bakteri pada media tanpa ekstrak adalah 142,67. Sedangkan pada media yang sudah diberi ekstrak etanol daun beluntas konsentrasi $2,5 \%, 3,5 \%, 4,5 \%, 5,5, \%$, dan $6,5 \%$ berturut-turut adalah 15,67, 10,67, 4, 0, 0 .

Perhitungan rata-rata jumlah koloni pada kontrol negatif yang digunakan dalam penelitian ini tidak menunjukkan penurunan jumlah koloni bakteri awal, atau menghasilkan rata-rata jumlah koloni bakteri yang sama dengan sebelum perlakuan. Penelitian ini juga mendapatkan hasil rata-rata jumlah koloni bakteri pada kontrol positif chlorhexidine gluconate $0,2 \%$ adalah tidak terdapat koloni bakteri.

\section{DISKUSI}

Penelitian ini dilakukan untuk mengetahui efektivitas ekstrak etanol daun beluntas Pluchea indica (L.) Less terhadap penurunan jumlah koloni bateri saliva. Penelitian ini menggunakan sampel saliva yang dilakukan pengenceran sebanyak lima kali kemudian diujikan pada media yang sudah diberi ekstrak dengan konsentrasi $2,5 \%$, $3,5 \%, 4,5 \%, 5,5 \%$ dan $6,5 \%$ serta diujikan pada kelompok kontrol positif chlorhexidine gluconate dan kelompok kontrol negatif aquades. Pada penelitian ini dilakukan perhitungan jumlah koloni bakteri dengan menggunakan colony counter. 
Pada penelitian pendahuluan Peneliti mencoba menambahkan nutrient broth pada saat saliva diencerkan namun hasilnya tidak dapat dilakukan perhitungan karena petridish terlalu dipenuhi koloni bakteri.

Hasil uji efektivitas antibakteri daun beluntas terbukti dapat menghambat pertumbuhan koloni bakteri dalam saliva dengan terjadinya penurunan rata-rata jumlah koloni bakteri. Hal ini terjadi karena adanya aktivitas antibakteri pada daun beluntas. Secara statistik, rata-rata jumlah koloni bakteri dalam saiva pada media tanpa dan dengan ekstrak ditunjukkan pada tabel 1. Kelompok perlakuan ekstrak etanol daun beluntas (Pluchea indica (L.) Less) mengalami penurunan rata-rata jumlah koloni bakteri bersamaan dengan peningkatan konsentrasi. Media tanpa diberikan ekstrak daun beluntas didapatkan jumlah rata-rata 142 koloni bakteri. Pada konsentarsi 2,5\% didapatkan15 koloni, 3,5\% 10 koloni, 4,5\% didapatkan 4 koloni, dan pada konsentrasi $5,5 \%$ dan $6,5 \%$ tidak didapatkan adanya koloni bakteri.

Adanya pengaruh ekstrak etanol daun beluntas (Pluchea indica (L.) Less) terhadap koloni bakteri saliva karena adanya kandungan flavonoid, alkoloid, minyak atsiri, dan tanin. Flavonoid merupakan golongan terbesar dari fenol yang memiliki sifat efektif dalam menghambat pertumbuhan bakteri dengan cara inaktivasi protein. Mekanisme kerja flavonoid sebagai antibakteri adalah membentuk senyawa kompleks dengan protein ekstraseluler pada dinding sel bakteri dan terlarut sehingga dapat merusak membran sel bakteri dan diikuti dengan keluarnya senyawa intraseluler ${ }^{16}$.

Mekanisme kerja alkaloid sebagai antibakteri diprediksi melalui penghambatan sintesis dinding sel yang akan menyebabkan lisis pada sel sehingga sel akan mati ${ }^{17}$.

Kandungan minyak atsiri dari daun beluntas mengandung benzil alkohol, benzil asetat, dan eugenol namun cara kerja minyak atsiri sebagai antibakteri masih belum diketahui, tetapi diduga aktivitas antibakteri ekstrak etanol daun beluntas didapatkan dari kandungan benzil alkohol yang merupakan suatu turunan alkohol. Mekanisme kerja benzil alkohol hampi sama dengan alkohol. Alkohol memiliki sifat pelarut lemak yang mendenaturasikan protein secara dehidrasi sehingga membran sel akan rusak dan terjadi inaktivasi enzim-enzim ${ }^{18}$.

Senyawa tanin berperan sebagai antibakteri karena memiliki kemampuan membentuk senyawa kompleks dengan protein melalui ikatan hidrogen, jika terbentuk ikatan hidrogen antara tanin dengan protein maka protein akan terdenaturasi sehingga metabolisme bakteri menjadi terganggu ${ }^{19}$.

Aktivitas antibakteri yang ada dalam ekstrak etanol daun beluntas (Pluchea indica (L.) Less) kemungkinan besar disebabkan oleh kandungan metabolit sekunder. Kandungan metabolit sekunder yang terdapat dalam daun beluntas berperan sebagai antibakteri kemungkinan karena senyawa-senyawa metabolit sekunder tersebut mampu menghambat pertumbuhan bakteri dengan merusak dinding sel 
bakteri, menghambat kerja enzim, mendenaturasi molekul protein dan asam nukleat serta menghambat sintesis protein pada bakteri ${ }^{15}$. Dalam penelitian ini belum dapat ditentukan secara pasti golongan senyawa aktif yang berperan sebagai antibakteri. Untuk mengetahui dengan pasti golongan senyawa yang aktif sebagai antibakteri maka perlu dilakukan penelitian lebih lanjut.

Banyak faktor yang dapat mempengaruhi peghambatan mikroorganisme oleh bahan atau proses antimikroba. Salah satu faktor tersebut adalah konsentrasi zat antimikroba. Sel-sel bakteri akan lebih cepat mati bila konsentrasi zat tersebut lebih tinggi ${ }^{20}$. Hal ini sesuai dengan hasil yang diperoleh pada penelitian yang telah dilakukan. Semakin tinggi konsentrasi ekstrak maka pertumbuhan bakteri semakin sedikit.

Di dalam rongga mulut dapat ditemukan berbagai bakteri seperti Streptococcus sp., Staphylococcus sp., Lactobacilus sp., dan Actinomycetes sp. Beberapa penelitian terdahulu membuktikan bahwa ekstrak daun beluntas dapat menghambat beberapa bakteri. Beberapa penelitian terdahulu menunjukkan bahwa ekstrak daun beluntas dapat menghambat pertumbuhan berbagai jenis bakteri patogen bagi manusia. Hasil penelitian Suhartono (2015) mendapatkan bahwa ekstrak daun etanol daun beluntas dapat menghambat pertumbuhan bakteri Escherichia coli 21. Hasil penelitian Wulandari et al. menunjukkan bahwa ekstrak etanol daun beluntas dapat menghambat pertumbuhan bakteri Staphylococcus aureus dan Pseudomonas aeruginosa $^{22}$.
Hasil penelitian pada kontrol positif chlorhexidine gluconate $0,2 \%$ tidak didapatkan adanya koloni bakteri, yang setara dengan ekstrak etanol daun beluntas konsentrasi 5,5\% dan 6,5\% (Tabel 1). Mekanisme antibakteri chlorhexidine adalah karena adanya interaksi molekul bermuatan positif dengan gugus fosfat pada dinding sel bakteri yang bermuatan negatif sehingga mengubah keseimbangan osmotik sel bakteri. Pada konsentrasi rendah chlorhexidine gluconate $0,2 \%$, zat dengan berat molekul rendah seperti kalium dan fosfor akan menyebabkan sel bakteri bocor dan pada konsentrasi yang lebih tinggi (2\%), chlorhexidine gluconate memiliki sifat bakterisida yang dapat mengendapkan sitoplasma bakteri sehingga menghasilkan kematian sel bakteri23.

Pada penelitian ini perlakuan konsentrasi ekstrak daun beluntas $6,5 \%$ tidak berbeda secara signifikan terhadap perlakuan konsentrasi ekstrak $5,5 \%$, sehingga diduga bahwa konsentrasi ekstrak 5,5\% merupakan konsentrasi yang optimum dalam menghambat pertumbuhan koloni bakteri saliva. Hal ini karena konsentrasi ekstrak yang lebih kecil mampu menimbulkan aktivitas antibakteri yang tidak berbeda signifikan dengan aktivitas antibakteri yang ditimbulkan oleh konsentrasi tertinggi.

Berdasarkan hasil yang telah didapat, bahwa semakin tinggi konsentrasi maka jumlah rata-rata koloni bakteri makin berkurang dan pada konsentrasi 5,5\% dan 6,5\% memiliki efek yang setara dengan chlorhexidine gluconate $0,2 \%$. 


\section{KESIMPULAN}

Berdasarkan hasil penelitian yang telah dilakukan, maka dapat disimpulkan bahwa ekstrak etanol daun beluntas (Pluchea indica (L) Less) efektif dalam menghambat pertumbuhan koloni bakteri dalam saliva dan semakin tinggi konsentrasi ekstrak etanol daun beluntas (Pluchea indica (L) Less) semakin menurunkan jumlah koloni bakteri.

\section{UCAPAN TERIMA KASIH}

Penulis mengucapkan terima kasih kepada Departemen Farmakologi dan Mikrobiologi Fakultas Kedokteran Universitas Mulawarman Program Studi Pendidikan Kedokteran Gigi Universitas Mulawarman serta Laboratorium Kesehatan Daerah Samarinda yang telah memberikan sarana untuk penelitian ini.

\section{DAFTAR PUSTAKA}

1. RI BK. Riset Kesehatan Dasar: RISKESDAS. 2017.

2. Widani N, Nasution Y. Perbandingan Oral Care Menggunakan Povidone lodine 1\% dengan Chlorhexidine 0,2\% Terhadap Jumlah Bakteri di Mulut Pada Pasien Penurunan Kesadaran 2015.

3. Nareswari A. Perbedaan efektivitas Obat Kumur Chlorhexidine Tanpa Alkohol Dibandingkan Dengan Chlorhexidine Beralkohol Dalam Menurunkan Kuantitas Koloni Vakteri Rongga Mulut 2010.

4. Swastini IGAAP. Kerusakan Gigi Merupakan Fokal Infeksi Penyebab Timbulnya Penyakit
Slstemik. Jurnal Kesehatan Gigi Vol.1 No.1. 2013: 63-68.

5. Brooks F, Carrol KC, Butel JS, Morse SA, Mietzner TA. Jawetz, Melnick, \& Adelberg Mikrobiologi Kedokteran. Jakarta: EGC; 2005.

6. Y S. A Review on the Human Oral Microflora. Research dan Reiew: Journal of Dental Sciences Volume 4. 2016.

7. Lamont RJ, Jenkinson HF. Oral Microbiologi at a Glance. Singapore: Wiley Blackwell; 2010.

8. Brooks GF, Carroll KC, Butel JS, Morse SA, Mietzner TA. Jawetz, Melnick, \& Aldelberg Mikrobiolgi Kedokteran. Jakarta: EGC; 2014.

9. Wibowo EAA. Perbandingan Kuantitas Bakteri Rongga Mulut Antara Berkumur dengan Klorheksidin dan Minyak Atsiri Bunga Cengkih (Syzygium aromaticum L.) 2010.

10.Agtini MD, Sintawati, Tjahja I. Fluor dan Kesehatan Gigi. Media Litbang Kesehatan Vol. XV No. 2. 2005: 25-31.

11.Kocak MM, Ozcan S, Sibel K, Topuz O, Erten $H$. Comparison of the Efficacy of Three Different Mouthrinse Solutions in Decreasing the Level of Streptococcus mutans in Saliva. European Journal of Dentistry. 2009: 57-61.

12.Nahak MM. Ekstrak Daun Beluntas (Puchea indica L) Dapat Menghambat Pertumbuhan Bakteri Streptococcus mutans. Jurnal kesehatan Gigi Vo. 1 No.1. 2013.

13.Setyowati FM. Etnofarmakologi dan Pemakaian Tanaman Obat Suku Dayak Tunjung di Kalimantan Timur. Media Litbang Kesehatan Volume XX Nomor 3. 2010. 
14. Hidayati RS, Napitupulu RM. Kitab Tumbuhan Obat. Jakarta: AgriFlo (Penebar Swadaya Grup); 2015.

15.Febriana HM, Amintarti S, Putra AP. Pengaruh Ekstra Daun Beluntas (Pluchea indica (L) Less) Terhadap Pertumbuhan Bakteri Escherichia coli. Jurnal Wahana-Bio Volume XIII. 2015.

16.(IndoBIC) IBIC. Senyawa Antimikroba dari Tanaman. 2005. Available at: http://indobic.or.id. Accessed April 28, 2018.

17.Lamothe R. Plant ANtimicrobial Agents and Their Effects on Plant and Human Pathogens. Int. J. Mol Sci 10. 2009: 3400-3419.

18.H AR, Cahyanto T, Sujarwo T, Lestari RI. Uji Aktivitas Antibakteri Daun Beluntas (Pluchea indica (L.) Less) Terhadap Propionibacterium Penyebab Jerawat. 2015: 141-161.

19.Angelina M, Turnip M, Khotimah S. Uji Aktivitas Antibakteri Ekstrak Etanol Daun Kemangi (Ocimum sanctum L.) Terhadap
Pertumbuhan Bakteri Ezcherichia coli dan Staphylococcus aureus. Jurnal Protobiont Vol.4(1). 2015: 184-189.

20.Pelczar J, Chan ECS, Krieg NR. Microbiology; 1993.

21. Suhartono. (2015). Skripsi Uji Efek Antibakteri Ekstrak Etanol Daun Beluntas (Pluchea indica (L) Less.) Ovenan Terhadap Escherichia coli Penyebab Diare. Samarinda.

22. Wulandari V, Husain DR, Sartini, Haedar N. Pengujuan Aktivitas Antibakteri Dari Ekstrak Etanol Daun Beluntas Pluchea indica Less. Terhadap Stapphylococcus aureus dan Pseudomonan aeruginosa. 2009.

23.Giordino L, Palazzi F, Zahed M, Giardino L, Palazzi F, Asgary S. Agonistic and Antagonistic Interactions between Chlorhexidine and Other Endodontic Agents: A Crtical Review. Iranian Endodontic Journal. 2014: 89-97. 